\title{
Penguatan Moderasi Beragama Melalui Media Sosial (Studi Terhadap Mahasiswa IAIN SAS Babel)
}

\author{
Pebri Yanasari \\ Fakultas Dakwah dan Komunikasi Islam \\ IAIN Syaikh Abdurrahman Siddik Bangka Belitung \\ Bangka, Indonesia \\ Pheb_he@yahoo.co.id
}

\begin{abstract}
Social media has an important role in strengthening religious moderation, this can be seen so enthusiastic students who skate on social media. So social media has potential in the dissemination of certain issues. This research focuses on strengthening religious moderation towards IAIN SAS Babel Students on social media used. This study presents information to students on thinking patterns and being moderate to issues circulating on social media, especially in terms of religion so that they are able to behave not only textually but are able to be contextually. This type of research, when viewed from the place of research, is classified as field research. Meanwhile, when viewed from data analysis method, this research uses qualitative and comparative descriptive method. The sampling method used by researchers is Non-probability while the sampling technique is Purposive Sampling (Judgment Sampling). The result of this study is that the students showed that they have little understanding of religious moderation, regardless of a deep understanding of certain issues if it is associated in people's lives. Surely this is the basic capital for students especially at IAIN SAS Babel when surfing the social world with issues of religious moderation able to filter and intelligently absorb news or issues that are widely spread through social media.
\end{abstract}

Keywords : religion, moderation, social media

\begin{abstract}
Abstrak
(Media sosial memiliki peran penting dalam penguatan moderasi beragama, hal ini dapat dilihat begitu antusiasnya mahasiswa yang berseluncur di media sosial. Sehingga media sosial memiliki potensi dalam penyebaran isu-isu tertentu. Penelitian ini focus kepada penguatan moderasi beragama terhadap Mahasiswa IAIN SAS Babel terhadap Media sosial yang digunakan. Penelitian ini menghadirkan informasi terhadap mahasiswa terhadap pola berpikir dan bersikap moderat terhadap isu-isu yang beredar di media sosial terutama dalam hal beragama sehingga mampu bersikap tidak hanya secara tekstual namun mampu secara konsteksual. Jenis penelitian ini, jika dilihat dari tempat penelitian (the place of research), tergolong penelitian lapangan (Field research). Sedangkan jika dilihat dari metode penganalisisan data, penelitian ini menggunakan metode deskriptif kualitatif dan komparatif. Metode pengambilan sampel yang digunakan oleh peneliti adalah Non-probabilitas sedangkan Teknik pengambilan sampelnya adalah Purposive Sampling (Judgment
\end{abstract}


Sampling). Hasil dari penelitian ini adalah para mahasiswa menunjukkan bahwa sudah sedikit banyak memahami moderasi beragama, terlepas pemahaman mendalam mengenai isu-isu tertentu jika dikaitkan dalam kehidupan bermasyarakat. Tentunya ini merupakan modal dasar bagi para mahasiswa terkhusus di IAIN SAS Babel ketika berselancar di dunia sosial dengan isu-isu moderasi beragama mampu menyaring dan menyerap dengan cerdas berita atau isu yang banyak disebarkan melalui media sosial.

Kata kunci: beragama, moderasi, media social

\section{A. Pendahuluan}

Bangsa Indonesia selalu diidentikkan dengan bangsa yang memiliki tingkat pluralitas masyarakat tinggi. Tentunya dengan jumlah etnis yang beragam, tidak hanya etnis namun juga ras, aliran kepercayaan, adat istiadat, kultur kedaerahan, agama terlebih bahasa. Sehingga bangsa Indonesia memiliki karakter, potensi, status ekonomi, kelas sosial, varian gerakan agama dan organisasi dan tentunya ideologi yang berbeda. ${ }^{1}$ Pada umumnya keragaman tersebut tidak hanya terdapat di negara berkembang namun juga dimiliki oleh negara-negara maju. ${ }^{2}$ Berkaitan dengan pluralitas bangsa di Indonesia, maka perbedaan terkadang menimbulkan perubahan sosial melalui adaptasi yang dilakukan sistem sosial. Pada implementasinya di masyarakat, pluralisme merujuk kepada konsep keseimbangan yang memelihara hubungan keragaman dan memelihara segala bentuk perbedaan menggunakan media seperti faktor kesamaan sebagai pengikat kesatuan.

Secara historis dan sosiologis menunjukkan bahwa penganut agama mayoritas bangsa ini adalah agama Islam. Fenomena ragam keberagamaan di Indonesia menunjukkan bahwa Indonesia diperkaya khazanah kehidupan keagamaan meskipun di satu sisi hal tersebut merupakan salah satu potensi

1 Ahmad Syahid, Riuh Di Beranda Satu:Peta Kerukunan Umat Beragama Di Indonesia (Jakarta: DEPAG RI, 2003).h.1

2 Mutakin dan Pasya, Dinamika Masyarakat Indonesia (Jakarta: Departemen Pendidikan Nasional, 2003).,h.52 
ancaman bagi pesatuan Negara Kesatuan Republik Indonesia (NKRI) . Tidak jarang Keragaman agama tersebut dapat mengakibatkan konflik, meskipun agama bukan merupakan factor utama, namun tidak dapat dielakkan bahwa agama seringkali dijadikan alat oleh kelompok yang memiliki kepentingan tertentu sebagai legitimasi terhadap tindakan tersebut. ${ }^{3}$ Fenomena perselisihan agama yang berkaitan dengan negara memang merupakan persoalan lebih sensitif dan seringkali menimbulkan pertikaian di masyarakat. Salah satu yang menjadi penyebabnya adalah rendahnya sikap toleransi antar umat beragama. Etika sari dalam Nur Salamah ${ }^{4}$ mencatat bahwa sekitar $31 \%$ mahasiswa memiliki sikap intoleren. Hal tersebut dapat menyebabkan penyebaan sikap radikalisme tidak bisa dianggap remeh. Tentunya sikap intoleran tersebut sedikit banyaknya akan berdampak pada keseimbangan sosial dan tatanan Negara dari segala lini kehidupan baik dari pendidikan, budaya, ekonomi, politik dan sebagainya.

Indonesia sudah banyak memiliki kasus yang berhubungan dengansikap radikalisme yang dicerminkan dari aksi terorisme, misalnya terjadinya baku tembak dan ledakan bom pada tahun 2016 antara teroris dan polisi di kawasan MH Thamrin Jakarta, terjadinya bom Bali pada tahun 2002 yaitu upaya pemisahan diri antara Gerakan Aceh Merdeka dari NKRI, pada tahun 2015 terjadinya pembakaran gereja di Aceh, bom bunuh diri di halaman Mapolresta Solo, ${ }^{5}$ dan masih banyak contoh kasus lainnya.

${ }^{3}$ Afif Rifai, Dalam Konflik Etno Religius Indonesia Kontemporer (Jakarta: DEPAG RI, 2003).,h.20

${ }^{4}$ Nur Salamah, Muhammad Arief Nugroho, and Puspo Nugroho, "Upaya Menyemai Moderasi Beragama Mahasiswa IAIN Kudus Melalui Paradigma Ilmu Islam Terapan," Quality 8, no. 2 (2020): 269, doi:10.21043/quality.v8i2.7517.

5 Rosyida Nurul Anwar and Siti Muhayati, "Upaya Membangun Sikap Moderasi Beragama Melalui Pendidikan Agama Islam Pada Mahasiswa Perguruan Tinggi Umum," AlTadzkiyyah: Jurnal Pendidikan Islam 12, no. 1 (2021): 1-15. 
Maka merasa diperlukan keterlibatan seluruh warga masyarakat dalam mewujudkan kedamaian terutama di bidang pendidikan yang menjadi perhatian khusus. Pendidikan ini nantinya diharapkan mampu melahirkan generasi yang cerdas dalam menyikapi permasalah perbedaan tersebut. Dalam pendidikan, dalam hal urusan agama dan keberagaman telah diatur secara tegas dan diberikan kebebasan kepada manusia dalam islam. Dalam Al-Qur'an adanya prinsip realitas pluralitas agama ${ }^{6}$ yaitu dalam surat AlBaqarah ayat 251, hidup berdampingan secara damai dalam surat Al-Kafirun (1-6) bahkan menganjurkan untuk saling berlomba dalam hal kebajikan (QS. Al-Maidah : 48).

Kamus Besar Bahasa Indonesia, Moderasi berarti kecenderungan berada dititik di tengah di antara dua buah kutub ekstrim ${ }^{7}$ sedangkan dalam bahasa arab, moderasi islam disebut dengan al-Wasathiyyah yang berasal dari kata al-Wasath yang bermakna terbaik dan paling sempurna. Sedangkan ada istilah Islamic Moderation dalam bahasa inggris. Dalam konteks Indonesia, al wasathiya meniscayakan penerapannya secara kontekstual dan adanya keseimbangan menurut teks kitab suci dalam hal beragama. Pertimbangan konteks dalam beragama berangkat dari prinsip maqasid atau tujuan ditetapkannya hukum islam (syari'ah).

Moderasi dalam islam mengedepankan sikap keterbukaan terhadap perbedaan yang ada. Selain itu, moderasi Islam tercerminkan dalam sikap yang tidak mudah untuk menyalahkan terlebih hingga tahap memberikan label "kafir" kepada kelompok yang memiliki pandangan yang berbeda. Dalam Hashim Kamali, moderasi merupakan unsur yang sangat penting,

\footnotetext{
${ }^{6}$ Hamdan, Riuh Di Beranda Satu: Peta Kerukunan Umat Beragama Di Indonesia (Jakarta: DEPAG RI, 2003).,h.182

${ }^{7}$ Kementerian Pendidikan dan Kebudayaan RI, Kamus Besar Bahasa Indonesia Pusat Bahasa (Jakarta: Gramedia Pustaka Utama, 2014).,h.50
} 
karena moderasi berhubungan dengan moral yang relevan dengan keadaan tertentu, tidak hanya kepentingan pribadi atau kelompok, namun sebagai bentuk integritas dan jati diri bangsa. ${ }^{8}$

Islam moderat merupakan sikap atau pandangan yang mengedepankan sikap berada pada posisi tengah terhadap sikap yang berlebihan dan bersebrangan sehingga tidak menjadi dominasi dalam sikap dan pikiran seseorang. Dengan kata lain, seorang muslim moderat merupakan muslim yang tidak berlebihan dalam memebri nilai atau aspek yang bertolak belakang dari yang semestinya. Adapun Khaled Abou el Fadl dalam The Great Theft di kutip oleh Misrawi adalah paham yang mengambil jalan tengah, yaitu paham yang tidak ekstrem kanan dan tidak pula ekstrem kiri. ${ }^{9}$

Dalam banyak fenomea keadaan keagamaan, moderasi beragama diharapkan menjadi angin segar yang dapat dijadikan solusi. Moderasi beragama tidak berarti berarti mengikuti arus yang ditentukan oleh bias model Barat yang cenderung mengedepankan kebebasan namun moderasi beragama dimaksud adalah nilai-nilai universal seperti ras hormat, kesetaraan, keseimbangan dan keadilan. Sikap moderasi beragama dalam penyampaian pesan-pesannya saat ini dinilai lebih mudah dengan dibarengi perkembangan teknologi informasi dan sosial media sebagai salah satunya. Moderasi beragama pun di media sosial tampaknya semakin menarik dengan tampilan yang dibuat dengan ragam bahasa yang mudah dipahami.

Media online memegang peranan yang sangat penting. ${ }^{10}$ Media online sebagai salah satu media korespondensi massal berperan dalam

${ }^{8}$ Hashim Mohammad Kamali, The Middle Pathof Moderation Islam-The Qur'anic Principle of Wasatiyyah, 1st ed. (London: Oxford University Press, 2015).h.98.

${ }^{9}$ Zuhairi Misrawi, Hadratussy aikh Hasyim Asy'ari Moderasi, Keutamaan, Dan Kebangsaan (Jakarta: Kompas Media Nusantara, 2010),,h.68.

${ }^{10}$ Rulli Nasrullah, Teori Dan Riset Media Siber (Cybermedia) (Jakarta: Kencana Prenadamedia Group, 2001).,h.1-2. 
mengembangkan suatu wacana. Wacana dalam komunikasi luas dapat berdampak dalam membentuk penilaian populer dan perspektif publik. Dengan demikian, setiap pembicaraan yang dibentuk oleh komunikasi yang luas mungkin akan dipandang sebagai kenyataan dalam kepribadian individu. Wacana itu sendiri adalah akibat dari perkembangan yang tidak sans esteem. Bicara dapat menunjukkan filosofi, pemahaman sosial dan perubahan sosial. Terlebih lagi, sesuai dengan pengaturan otentik di mana pembicaraan disampaikan. Pada dasarnya, berbicara adalah jenis kegiatan sosial yang disampaikan sesuai keinginan membuat teks.

Media online adalah bagian dari media baru. Substansi yang sangat cerdas di media baru sangat tinggi. Media berbasis web, dikutip dari Wikipedia, dicirikan sebagai media online, dengan kliennya memiliki opsi untuk dengan mudah mengambil bagian, berbagi, dan membuat konten termasuk situs web, organisasi informal, wiki, diskusi, dan dunia maya. Ardianto dalam buku Correspondence 2.0 mengungkap bahwa media online berbasis web, yang disebut komunitas informal online, bukanlah komunikasi luas online karena media berbasis web memiliki kekuatan sosial yang sangat mempengaruhi penilaian umum yang tercipta di arena publik. Menggalang bantuan atau perkembangan massa dapat dibingkai sebagai akibat dari kekuatan media online karena apa yang ada di media berbasis web telah terbukti memiliki pilihan untuk membentuk perasaan, mentalitas, dan perilaku publik atau area lokal untuk membuka keadaan yang menjanjikan bagi masing-masing. pihak yang dibutuhkan untuk eksis secara lebih luas. Khususnya bagi individu yang dinamis melalui media online. Melalui status, ucapan, catatan, dan berbagai kantor melalui media online, banyak individu berusaha untuk menunjukkan realitas mereka dengan selalu menyegarkan setiap pergantian peristiwa saat ini. Sebuah kemajuan yang dianggap sulit 
untuk diteruskan, di ranah Media Online, kemajuan ini dapat dimanfaatkan oleh masyarakat secara luas, tidak terkecuali di kalangan mahasiswa, khususnya mahasiswa yang memang sangat dekat dengan media berbasis web dalam kesehariannya sebagai rutinitas.

Mahasiswa IAIN SAS Bangka Belitung sebagian besar dapat dikategorikan masih masuk fase masa remaja menuju dewasa awal, masa dimana memiliki kepekaan yang begitu kuat terhadap hal-hal yang baru sehingga sangat mudah beradaptasi dengan hal baru tersebut terlebih media sosial menawarkan fitur-fitur yang mengasyikkan tanpa mempedulikan konten-konten yang terkandung dalam fitur tersebut bernilai positif maupun negatif. Hal tersebut merupakan tantangan bagi mahasiswa agar dapat membentengi diri untuk bertindak sebagaimana nilai yang berlaku namun tidak dipungkiri bahwasannya media menawarkan nilai-nilai hedonis bagi mereka. Media sosial di satu sisi menawarkan manfaat positif bagi mobilitas kebutuhan siswa/siswi dalam mengakses pelajaran tertentu namun di sisi lain dapat membawa dampak negatif bagi perkembangan pola fikir dalam hal ini mengenai moderasi beragama mengingat banyak berita-berita tentang keagamaan di media sosial secara gambling di pertontonkan secara umum.

\section{A. Metodelogi Penelitian}

Jenis penelitian ini, jika dilihat dari tempat penelitian (the place of research), tergolong penelitian lapangan (Field research). Sedangkan jika dilihat dari metode penganalisisan data, penelitian ini menggunakan metode deskriptif kualitatif dan komparatif. Sedangkan pendekatan 
penelitian ini adalah pendekatan fenomenologi. Fenomenologi yang dimaksud dalam penelitian ini digunakan untuk mencari hakekat atau esensi penguatan moderasi melalui media sosial.

Metode pengambilan sampel yang digunakan oleh peneliti adalah Non-probabilitas yaitu suatu teknik pengambilan sampel dimana setiap anggota sample yang diambil populasi memiliki peluang yang sama untuk dijadikan anggota sampel. Teknik pengambilan sampelnya adalah Purposive Sampling (Judgment Sampling) yaitu teknik pengambilan sample berdasarkan penilaian karakteristik anggota sample yang disesuaikan dengan tujuan peneliti. ${ }^{11}$

Pengumpulan data dilakukan penulis dengan teknik pengumpulan data primer dan sekunder sebagai berikut:1). Data primer adalah a). Kuisioner, yaitu teknik pengumpulan data dengan menggunakan pertanyaan-partanyaan tertulis untuk memperoleh informasi dari responden yaitu fasilitas pelayanan, promosi dan produk b). Observasi, yaitu dengan melakukan pengamatan langsung ke lapangan c). Direct Interview, melakukan wawancara atau tanya jawab langsung kepada responden. Dalam hal ini yang akan menjadi sampel adalah perwakilan daripada Mahasiswa IAIN SAS Babel.

\section{B. Pembahasan}

\section{Telaah Pustaka}

Penelitian yang berkaitan dengan moderasi beragama melalui media sosial telah dilakukan oleh para penelitian sebelumnya.

${ }^{11}$ Purwanto Suharyadi, Statistik Untuk Ekonomi Keuangan Modern, Dua (Jakarta: Salemba Empat, 2004).,h.325 
Pertama, penelitian yang dilakukan Fatmawatianwar Religious Moderation Campaign Through Sosial Media At Multikultural Communities. ${ }^{12}$ Penelitian ini menyimpulkan bahwa Media berbasis web memainkan peran penting dalam menyebarkan dan menyampaikan pesan-pesan ketat dalam kehidupan yang ramah dan publik. Oleh karena itu, upaya gencaran dalam media sosial yang ketat melalui media berbasis web harus dibuat untuk membendung perkembangan pembicaraan ketat yang akhir-akhir ini pada umumnya akan menjadi elit dan terus-menerus menyalahkan berbagai kelompok..

Kedua, penelitian yang dilakukan Wuri Pesan Kementerian Agama dalam Moderasi Melalui Media Sosial Instagram. ${ }^{13}$ Penelitian ini menyimpulkan bahwa Dilihat dari jumlah unggahan setiap bulannya, unggahan normal pada angka 28,7 postingan menunjukkan bahwa jika dibandingkan dengan 30 hari dalam sebulan, akun @ kemenag_ri tidak memposting setiap hari. Postingan terbanyak adalah foto pribadi yang berkisar hingga $42 \%$ namun secara kebetulan hanya mendapatkan $29 \%$ preferensi, bahkan ada tambahan postingan dari IG televisi yang menyelesaikan 45 postingan yang mencapai preferensi 39\%. Bagaimanapun, postingan foto pribadi menarik hingga mencapai pada persentase $86 \%$ di kolom komentar. Salah satu elemen dari hashtag office adalah untuk mengikutsertakan pemilik akun, namun dari lima hashtag yang banyak digunakan oleh akun

${ }^{12}$ Fatmawati Anwar, "Religious Moderation Campaign Through Social Media At Multicultural Communities," Jurnal KURIOSITAS Media Komunikasi Sosial Dan Keagamaan 12, no. 2 (2019): 3.

${ }^{13}$ Wuri, "Kementerian Agama Dalam Moderasi Melalui Media Sosial Instagram," Jurnalisa 6, no. 01 (2020): 8. 
@ kemenag_ri, hashtag \#haji2019 ke atas dari 74 postingan mendapat reaksi paling banyak dari netizen. Sementara itu, tagar \#SpreadPeace yang digunakan mencapai 207 postingan dan baru mencapai 5.643 postingan. Memang, hashtag ini bisa berupa konten atau gambar yang mengarahkan berbagai individu. Akun @kemenag_ri belum menambah sharing office, jadi masih ada postingan yang belum nyambung dengan kumpul-kumpul terkait. Jelas, ini adalah upaya untuk menjadi sensasi web. Jika substansi melalui media online menjadi viral, siklus dahsyat menuju keramaian di era RI 4.0 bisa dibilang berbuah manis. Kementerian Agama juga dapat menyusun program yang terorganisir, besar dan tepat pada catatan kantor untuk mulai peka terhadap posting dengan bagian-bagian yang memperkuat kerjasama yang membantu kualitas nilai-nilai moderasi keberagaman umat dalam beragama.

Ketiga, Penelitian yang dilakuan oleh Ari Wibowo Kampanye Moderasi Beragama di Facebook; Bentuk dan Strategi Pesan. ${ }^{14}$ Penelitian ini memfokuskan kampanye moderasi beragamanya di satu media saja yaitu facebook yang menawarkan bentuk dan strategi pesan dalam mengkampanyekan moderasi beragama yaitu pertama harus bersifat ideologically-oriented (berorientasi pada perubahan sikap perilaku dan pandangan publik), kedua pesan kampanye harus informative dan persuasive (didasari data dan fakta) serta dapat memengaruhi pengguna Facebook lainnya untuk ikut membuat kampanye (sosial campaign) tentang moderasi beragama. Pesan kampanye moderasi beragama di Facebook tidak mesti harus berisi

14 Ari Wibowo, "Kementerian Agama Dalam Moderasi Melalui Media Sosial Instagram,” Edugama : Jurnal Kependidikan Dan Sosial Keagamaan 5, no. 1 (2019): 9. 
tulisan, dapat juga berupa gambar (animasi) ilustratif atau video eduksi berdurasi pendek.

Keempat, penelitian yang dilakukan oleh Engkos Kosasih Literasi Media Sosial dalam Pemasyarakatan Sikap Moderasi Agama. ${ }^{15}$ Penelitian tersebut menyimpulkan bahwa kemahiran media online merupakan salah satu upaya utama yang harus dilakukan untuk membantu daerah setempat dalam menyusun dan memilih data yang mereka peroleh di antara data-data yang mendekat yang tak hentihentinya, agar tidak terjebak dalam kubangan data yang salah di Internet. Kelompok masyarakat ini diandalkan memiliki daya nalar dasar dan dapat diterima dalam menentukan pilihan terbaik dalam menyikapi penyebaran data melalui media online. Hal ini akan menyelamatkan wilayah lokal sebagai klien media online dari jerat mentalitas ekstremis dalam beragama karena hasutan data dari media berbasis web. Mental wasathiyyah ini bercampur secara total melalui media online ketika klien saat ini dapat membaur, memilih dan mengetahui isi data yang mengalir selama ini. Masyarakat pada umumnya harus membentengi alat pemisah data secara efisien sehingga dapat mengawasi dan mengarahkan setiap contoh data yang mendekati dan menjadi terbiasa untuk mengecek data yang baru saja didapat. Akibatnya, akan dibuat edukasi media online yang akan mendorong mentalitas keseimbangan yang ketat secara lokal, lautan data media sosial akan sangat dikendalikan melalui penguasaan media berbasis web ini.

${ }^{15}$ Engkos Kokasih, "Literasi Media Social Dalam Pemasyarakatan Sikap Moderasi Beragama,” Bimas Islam 12, no. 01 (2019): 2. 
Kelima, Penelitian yang dilakukan oleh Eko Agung Ady Suprapto Wacana Moderasi Beragama (Analisis Wacana Van Dijk di Media Kompas.com dan Republika Online). ${ }^{16}$ Hasil dari penelitian yang dilakukan adalah bahwa Wacana Keseimbangan agama yang ditunjukkan oleh media Kompas.com adalah Kompas.com sejauh teks berita, semua berita di atas termasuk berita langsung, yang merupakan informasi nyata. Pembuatan berita tentunya menggunakan strategi piramida terbalik yang menitikberatkan pada substansi utama, kemudian pada saat itu substansi yang kurang signifikan dan pada bagian bawah berita adalah substansi yang tidak relevan. Kemudian, pada saat itu pembicaraan tentang kontrol yang ketat menurut media Kompas.Com digambarkan dengan filosofi damai dalam menyampaikan pelajaran Islam, pemanfaatan spekulasi normal sebagai instrumen dalam mengartikan dan mendapatkan agama, dan penggunaan metodologi logis dalam mendapatkan agama. . Pembicaraan kontrol ketat yang ditunjukkan oleh media Republika Online adalah Republika Online sejauh teks berita, semua berita di atas termasuk berita langsung adalah informasi asli. Penyusunan berita tentunya menggunakan strategi piramida yang disusun ulang seperti Kompas, yang menitikberatkan pada substansi utama, kemudian pada saat itu substansi yang kurang signifikan dan pada bagian bawah berita adalah substansi immaterial. Kemudian, pada saat itu pembicaraan tentang pengawasan ketat menurut Republika Online dipisahkan dengan penerimaan penghargaan-penghargaan masa kini dalam kehidupan seperti ilmu pengetahuan dan inovasi,

${ }^{16}$ EAA Suprapto, "Wacana Moderasi Beragama (Analisis Wacana Van Dijk Di Media Kompas.Com Dan Republika Online)" (IAIN Purwokerto, 2020). 
pemerintahan kerakyatan, kebebasan bersama, dan lain sebagainya. Kemudian, pada saat itu kekuasaan adalah kepemilikan yang dimiliki oleh suatu perkumpulan atau individu-individunya, dalam hal ini Dinas Agama, yang secara langsung atau tidak langsung berdampak pada pembicaraan tentang Keseimbangan yang Ketat. Diterimanya Keseimbangan Ketat tergantung pada isu radikalisme yang tak terhindarkan, yang menyebabkan Dinas Agama berbaur kemungkinan keseimbangan agama melalui media online seperti dua perkumpulan massa besar, khususnya Nahdlatul Ulama dan Muhammadiyah. Penelitian ini memiliki persamaan dengan penelitian sebelumnya yaitu penelitian mengenai moderasi beragama melalui media sosial. Sedangkan perbedaan penelitian ini dengan penelitian sebelumnya adalah pendekata penelitian yaitu menggunakan pendekatan fenomenologi.

\section{Landasan teori dan Kerangka Konseptual}

Penelitian ini menggunakan teori behavioristik ${ }^{17}$ Dalam teori behavioristik, proses belajar merupakan suatu perubahan dari tingkah laku yang bisa diamati secara langsung dari hubungan stimulus dan respon mengikuti prinsip-prinsip yang ada. ${ }^{18}$

Dalam teori ini juga, banyak daripada para penganutnya berpendapat jika cukup bagi seseorang dalam mengaplikasikan stimulus dan respon yang diterima jika respon yang diberikan merupakan respon yang baik.

Keyakinan para behavioris setiap manusia lahir dengan tidak membawa warisa berupa kecerdasan, bakat, perasaan dan yang lainnya

${ }^{17}$ Asri Budiningsih, Belajar Dan Pembelajaran (Jakarta: Rineka Cipta, 2005).,h.21

18 Dahar Ratna Wilis, Teori-Teori Belajar (Jakarta: Depdikbud Dirjen Lembaga Tenaga Kependidikakn, 1988).h.47 
yang bersifat abstrak lainnya ${ }^{19}$ dan memiliki anggapan jika manusia bersifat mekanistik yang berarti merespon pada lingkungan dengan control terbatas yang memiliki peran sedikit terhadap diri mereka sendiri. Konsep behavioristic melihat bahwa perilaku seorang individu adalah produk belajar yang dapat dirubah dengan mensiasati situasi belajar yang didukung dengan berbagai penguatan (reinforcement) untuk memperoleh perilaku dan hasil belajar sesuai yang diharapkan ${ }^{20}$ Proses tersebut akan timbul ketika manusia sudah memiliki kontak dengan lingkungan sosial budayanya serta alam dalam menjalani proses pendidikan. Individu akan memiliki keterampilan, sifat abstrak tergantung dengan proses belajar yang dialami dengan lingkungannya. Albert Bandura sebagai neobehaviorism muncul dengan teorinya Sosial Learning Theory (Teori belajar sosial). ${ }^{21}$

Teori ini merupakan gabungan antara teori classical dan operant conditioning Hal yang paling mendasar dalam teori ini adalah kemampuan seseorang dalam menerima dan mengolah informasi dari perilaku orang lain hingga kemudian mampu memutuskan tentang perilaku yang akan diikuti dan selanjutnya akan diaplikasikan sesuai dengan apa yang telah dipilih. Artinya tingkah laku manusia itu bukan semata-mata refleks otomatis atas stimulus (S-R Bond), namun akibat

${ }^{19}$ Muhibbin Syah, Psikologi Belajar, Cetakan 3 (Jakarta: Raja Grafindo Persada, 2004).,h.53

${ }^{20}$ Sigit Sanyata, "Teori Dan Aplikasi Pendekatan Behavioristik Dalam Konseling," Paradigma 14, no. 1 (2012): 3.

21 Agus Riyanto, "Teori Belajar Bandura Dan Implementasinya Dalam $\begin{array}{llll}\text { Pembelajaran," } & 19 & \text { Maret } & 2019,\end{array}$ https://www.google.com/url?sa=t\&rct=j\&q=\&esrc=s\&source=web\&cd=\&cad=rja\&uact=8 \&ved=2ahUKEwjK--

GltO7yAhUz8HMBHSe0DiEQFnoECCIQAQ\&url=https\%3A\%2F\%2Fdocplayer.info\%2F 201100156-Teori-belajar-behaviorisme-albert-bandura-dan-implikasinya-dalampembelajaran-bahasa. 
reaksi yang timbul sebagai hasil interaksi antara lingkungan dengan skema kognitif manusia itu sendiri. ${ }^{22}$

Teori belajar sosial sebagai pendekatan terhadap proses perkembangan dan moral seseorang dapat dilakukan dengan mengadakan conditioning (pembiasaan merespon) dan imitation (peniruan). Dalam pembiasaan ini dibutuhkan adanya reward dan punishment, sedangkan dalam peniruan peran dari guru dan orangtua memainkan peranan penting sebagai role model yang dapat dicontoh dalam perilaku sosial para siswa.

Dari berbagai pendapat pakar behavioris, dapat ditarik benang merah antara pendapat yang satu dengan yang lainnya, walaupun pada hakikatnya sama. Semua pakar behavioris sepakat bahwa belajar merupakan hubungan antara stimulus dan respon. Akan tetapi, Thorndike menggunakan trial-and-error sebagai pemecahannya. Sedangkan Pavlov dan Skinner membentuk pembiasaan tingkah laku dengan bantuan reinforcement (penguatan). Sementara Guthrie berpandangan bahwa hasil belajar itu bukan karena banyaknya hubungan stimulus dan respon, akan tetapi dikarenakan dekatnya hubungan antara keduanya. Watson sebaliknya, memandang bahwa belajar merupakan menanamkan rangkaian asosiasiasosiasi ke dalam sistem susunan saraf. Sedangkan Bandura dengan teori belajar sosialnya, lebih menekankan belajar sebagai proses pengambilan keputusan dalam bertingkah laku dengan cara peniruan dan pembiasaan melalui informasi yang didapatkan dari lingkungan sekitarnya. Secara filosofis, behavioristik meletakkan manusia dalam kutub yang berlawanan, dimana seharusnya manusia bersifat dinamis, akan tetapi dituntut untuk bersifat mekanistik.

${ }^{22}$ Mahmud Dimyati, Psikologi Pendidikan (Jakarta: Depdikbud, 1989).,h. 106 
Namun demikian, pandangan behavioris modern menjelaskan bahwa faktor lingkungan memiliki kekuatan alamiah bagi manusia dalam stimulus-respon, sesuai dengan konsep sosial learning theory dari Albert Bandura. Artinya manusia merupakan hasil dari pengkondisian sosio kultural bukan semata-mata terbentuk dari hubungan antara stimulus dan respon. Konsep ini menghilangkan pandangan manusia secara mekanistik dan deterministik, sehingga memberikan peluang kebebasan dan menambah keterampilan untuk memiliki lebih banyak opsi dalam melakukan respon.

Bagaimana hubungan antara penguatan moderasi beragama melalui media sosial jika dikorelasikan dengan sosial learning theory? Dalam analisa Bandura yang menekankan belajar sebagai proses pengambilan keputusan dalam bertingkah laku dengan cara peniruan dan pembiasaan melalui informasi yang didapatkan dari lingkungan sekitarnya, maka Mahasiswa IAIN SAS sedikit banyaknya akan meniru dalam bertingkah laku dari media sosial.

\section{Hasil Penelitian}

Penelitian dilakukan terhadap beberapa sampel secara acak. Dari hasil penelitian terhadap perwakilan mahasiswa IAIN SAS Bangka Belitung, banyak dikalangan mahasiswa yang menggunakan lebih dari satu media sosial seperti Facebook, Instagram, WhatsApp, Twitter bahkan menjajah ke ranah channel Youtube. Dari berbagai media sosial tersebut tentunya dikalangan mahasiswa tersebut memiliki kesempatan dan potensi menerima maupun menyebarkan informasi apapun terlebih yang berkaitan dengan moderasi beragama terlepas apa kepentingan mereka memiliki lebih dari satu media sosial. Terlebih instagram dan Twitter setiap detiknya memiliki 
informasi yang update diberbagai bidang. Seharusnya media sosial tersebut dapat digunakan dengan bijak.

Setelah dilakukan analisis hasil pengisian angket sampel mahasiswa, kepentingan para mahasiswa dalam menggunakan lmedia sosial memiliki jawaban yang bervariasi, namun secara umum dapat ditarik kesimpulan bahwa media sosial dianggap penting sebagai media komunikasi, media mendaptkan informasi dan mengekspresikan diri. Pertama, sebagai media komunikasi terlebih yang terlibat dalam organisasi dalam maupun luar kampus ini tentunya media sosial memiliki keterlibatan sebagai sarana penyambung informasi dan komunikasi dengan berbagai jaringan untuk kerjasama. Kedua, sebagai media informasi. Sebagai mahasiswa sudah selayaknya untuk lebih mudah dan murah dalam mendapatkan informasi menggunakan media sosial terlebih pada masa pandemi perkuliahan dilakukan secara online, terlepas apapun informasi yang diterima dan dicari oleh mahasiswa di media sosial, ini akan memberikan perubahan perilaku pada kehidupan sosial seperti mereka cenderung berbicara dan berperilaku dengan apa yang dilihat dan dibaca dari informasi yang bersumber dari media sosial. Ketiga, untuk mengekspresikan diri. Media sosial sebagai wahana ekspresi diri dan imajinasi di kalangan mahasiswa.

Dari hasil penyebaran angket pada mahasiswa didapatkan hasil bahwa mahasiswa sudah memahami apa yang dimaksud dengan moderasi beragama khususnya dalam bermedia sosial. Data tersebut didapat dari penjabaran jawaban mahasiswa terhadap pertanyaan peneliti, hal ini tentunya merupakan kunci bagi mahasiswa dalam berselancar di media sosial sehingga mereka mampu menampung hingga menyaring informasi yang didapat dengan memahaminya terlebih dahulu sebelum disebarluaskan bahkan diterapkan di masyarakt. Hal ini sangat penting dan mendasar mengingat 
kekuatan media sosial tidak diragukan lagi dalam mencerna informasi yang didapat terlebih untuk kalangan mahasiswa sebagai agent of change. Secara umum, Moderasi beragama akan berdampak pada toleransi dan kerukunan dalam beragama karena dalam perkembangan paham ekstrim dalam berbagai lini sosial akan mengancam sendi-sendi kebangsaan. Juga dengan nilai-nilai agama yang harus dijaga lalu dipadukan dengan nilai-nilai kearifan dan adatistiadat local, tentunya ini merupakan kunci sebelum mahasiswa benar-benar menjadi system dalam masyarakat nantinya.

Adapun isu-isu yang banyak diminati oleh mahasiswa dalam hal moderasi beragama di media sosial diantaranya :

\begin{tabular}{|l|l|}
\hline No & \multicolumn{1}{|c|}{ Isu } \\
\hline 1. & $\begin{array}{l}\text { Kebudayaan luar yang masuk, kemudian dipadukan atau } \\
\text { digabungkan dengan agama yang telah kita anut sehingga terjadi } \\
\text { akulturasi dalam beragama. }\end{array}$ \\
\hline 2. & $\begin{array}{l}\text { Isu Toleransi, yang sebenarnya sudah jelas diterangkan dalam } \\
\text { Islam tetapi masih banyak orang yg gagal paham dan dibeberapa } \\
\text { kasus ada media yg mereka mencari makan dengan gagal paham } \\
\text { itu sendiri. }\end{array}$ \\
\hline 3. & Peran Ulama dan Cendekiawan berwawasan Moderat. \\
\hline 4. & Organisasi Masyarakat (Ormas) Islam di Indonesia \\
\hline 5. & Toleransi Umat beragama \\
\hline 6. & Radikalisasi \\
\hline
\end{tabular}

Dari gambaran isu yang dipilih oleh para mahasiswa menunjukkan bahwa sudah sedikit banyak memahami moderasi beragama, terlepas pemahaman mendalam mengenai isu-isu tertentu jika dikaitkan dalam kehidupan bermasyarakat. Tentunya ini merupakan modal dasar bagi para mahasiswa terkhusus di IAIN SAS Babel ketika berselancar di dunia sosial dengan isu-isu moderasi beragama mampu menyaring dan menyerap dengan 
cerdas berita atau isu yang banyak disebarkan melalui media sosial. Media sosial yang merupakan jembatan bagi kalangan mahasiswa dalam menyerap informasi di dunia maya yang memiliki peran penting dalam memengaruhi pola pikir dalam bersosialisasi sehingga hal tersebut merupakan PR bersama menyikapi media sosial kearah moderasi beragama.

\section{Kesimpulan}

Dari paparan diatas, dapat diambil kesimpulan bahwa media sosial menjadi salah satu upaya yang sangat memengaruhi mahasiswa IAIN SAS Babel dalam membantu menerima penyebaran isu dan informasi kehidupan beragama. Mahsiswa diharpkan memiliki daya fikir kritis dan cerdas dalam mengambil keputusan yang tepat dalam menyikapi dan menanggapi informasi atau isu beragama di media sosial. Hal tersebut mampu menjadi fondasi utama mahasiswa sebagai pengguna media sosial dalam menyikapi sikap radikal dalam keberagamaan hasil dari informasi yang bersifat provokatif dari media sosial.

Menurut penelitian sampel Mahasiswa IAIN SAS Babel. Mereka sudah memiliki kemampuan merespon, mengolah, dan mengambil konten atau informasi yang beredar di media sosial. Mahasiswa sudah seharusnya tetap dapat mencerna dan mengelola setiap pola semua informasi yang diterima dan selalu membiasakan diri untuk mengkroscek informasi yang didapat. Dengan demikian penguatan moderasi beragama di kalangan mahasiswa dapat diterapkan dengan baik dan semaksimal mungkin tanpa khawatir mahasiswa akan terpengaruh atas isu / informasi yang di dapat dari media sosial. 


\section{Daftar Pustaka}

Anwar, Fatmawati. "Religious Moderation Campaign Through Social Media At Multicultural Communities.” Jurnal KURIOSITAS Media Komunikasi Sosial Dan Keagamaan 12, no. 2 (2019): 3. Anwar, Rosyida Nurul, and Siti Muhayati. "Upaya Membangun Sikap Moderasi Beragama Melalui Pendidikan Agama Islam Pada Mahasiswa Perguruan Tinggi Umum.” Al-Tadzkiyyah: Jurnal

Pendidikan Islam 12, no. 1 (2021): 1-15.

Budiningsih, Asri. Belajar Dan Pembelajaran. Jakarta: Rineka Cipta, 2005. Dimyati, Mahmud. Psikologi Pendidikan. Jakarta: Depdikbud, 1989. Hamdan. Riuh Di Beranda Satu : Peta Kerukunan Umat Beragama Di Indonesia. Jakarta: DEPAG RI, 2003.

Kamali, Hashim Mohammad. The Middle Pathof Moderation Islam-The Qur'anic Principle of Wasatiyyah. 1st ed. London: Oxford University Press, 2015.

Kementerian Pendidikan dan Kebudayaan RI. Kamus Besar Bahasa Indonesia Pusat Bahasa. Jakarta: Gramedia Pustaka Utama, 2014. Kokasih, Engkos. "Literasi Media Social Dalam Pemasyarakatan Sikap Moderasi Beragama,." Bimas Islam 12, no. 01 (2019): 2.

Misrawi, Zuhairi. Hadratussyaikh Hasyim Asy'ari Moderasi, Keutamaan,

Dan Kebangsaan. Jakarta: Kompas Media Nusantara, 2010.

Nasrullah, Rulli. Teori Dan Riset Media Siber (Cybermedia). Jakarta:

Kencana Prenadamedia Group, 2001.

Pasya, Mutakin dan. Dinamika Masyarakat Indonesia. Jakarta: Departemen Pendidikan Nasional, 2003.

Ratna Wilis, Dahar. Teori-Teori Belajar. Jakarta: Depdikbud Dirjen

Lembaga Tenaga Kependidikakn, 1988. 
Rifai, afif. Dalam Konflik Etno Religius Indonesia Kontemporer. Jakarta: DEPAG RI, 2003.

Riyanto, Agus. "Teori Belajar Bandura Dan Implementasinya Dalam Pembelajaran." 19 Maret 2019, 2019.

https://www.google.com/url?sa=t\&rct=j\&q=\&esrc=s\&source=web\&cd $=\& c a d=$ rja $\& u a c t=8 \& v e d=2$ ahUKEwjK--

GltO7yAhUz8HMBHSe0DiEQFnoECCIQAQ\&url=https\%3A\%2F\%2

Fdocplayer.info\%2F201100156-Teori-belajar-behaviorisme-albertbandura-dan-implikasinya-dalam-pembelajaran-bahasa.

Salamah, Nur, Muhammad Arief Nugroho, and Puspo Nugroho. "Upaya Menyemai Moderasi Beragama Mahasiswa IAIN Kudus Melalui Paradigma Ilmu Islam Terapan." Quality 8, no. 2 (2020): 269. doi:10.21043/quality.v8i2.7517.

Sanyata, Sigit. "Teori Dan Aplikasi Pendekatan Behavioristik Dalam

Konseling." Paradigma 14, no. 1 (2012): 3.

Suharyadi, Purwanto. Statistik Untuk Ekonomi Keuangan Modern. Dua. Jakarta: Salemba Empat, 2004.

Suprapto, EAA. "Wacana Moderasi Beragama (Analisis Wacana Van Dijk Di Media Kompas.Com Dan Republika Online)." IAIN Purwokerto, 2020.

Syah, Muhibbin. Psikologi Belajar. Cetakan 3. Jakarta: Raja Grafindo Persada, 2004.

Syahid, Ahmad. Riuh Di Beranda Satu:Peta Kerukunan Umat Beragama Di Indonesia. Jakarta: DEPAG RI, 2003.

Wibowo, Ari. "Kementerian Agama Dalam Moderasi Melalui Media Sosial Instagram.” Edugama : Jurnal Kependidikan Dan Sosial Keagamaan 5, no. 1 (2019): 9. 